\title{
Obtaining of $\mathrm{La}_{0.6} \mathrm{Sr}_{0.4} \mathrm{Co}_{0.2} \mathrm{Fe}_{0.8} \mathrm{O}_{3-\delta}$ Nanopowder Using the Glycol-Citrate Method
}

\author{
T. L. Simonenko ${ }^{a}$ *, N. P. Simonenko ${ }^{a}$, E. P. Simonenko ${ }^{a}$, \\ V. G. Sevastyanov ${ }^{a}$, and N. T. Kuznetsov ${ }^{a}$ \\ ${ }^{a}$ Kurnakov Institute of General and Inorganic Chemistry, Russian Academy of Sciences, Moscow, 119991 Russia \\ *e-mail: egorova.offver@gmail.com
}

Received November 20, 2020; revised November 27, 2020; accepted November 30, 2020

\begin{abstract}
The process of glycol-citrate synthesis of nanodispersed oxide with the composition $\mathrm{La}_{0.6} \mathrm{Sr}_{0.4} \mathrm{Co}_{0.2} \mathrm{Fe}_{0.8} \mathrm{O}_{3-\delta}$ have been studied. The resulting nanopowder has been examined using a complex of modern methods of physicochemical analysis. The thermal behavior of the obtained powder in air in the temperature range of $20-1000^{\circ} \mathrm{C}$ has been investigated using synchronous TGA/DSC analysis. As a result, the optimal conditions for the sample heat treatment have been determined, to lead to the formation of a singlephase nanocrystalline oxide. Using X-ray diffraction analysis, IR spectroscopy, and energy-dispersive X-ray spectroscopy, it has been shown that the proposed synthesis method is convenient and effective for obtaining a highly dispersed powder of the specified composition with the target crystal structure. Scanning electron microscopy has been applied to analyze the morphology of the oxide nanopowder and determine the average particle and pore size.
\end{abstract}

Keywords: glycol-citrate method, lanthanum oxide, strontium oxide, iron oxide, cobalt oxide, cathode, fuel cell

DOI: $10.1134 / \mathrm{S} 0036023621040203$

\section{INTRODUCTION}

According to estimates of various international news agencies, by 2048 the level of global energy consumption will increase by 50\% compared to 2012 . Given the inertial development of the energy sector and the use of traditional energy sources as the main ones, this fact may entail negative environmental consequences because of growing volumes of emissions that pollute the atmosphere and the environment as a whole $[1,2]$. In this regard, many developed countries are pursuing an active policy of searching for and integrating environmentally friendly renewable energy sources into the existing energy supply system [3, 4]. To date, considerable attention is attracted by technologies of electrochemical power engineering, in particular, electrochemical generators of electricity, i.e., solid oxide fuel cells (SOFCs) [5, 6]. This type of device allows one to convert directly the chemical energy of the redox reaction (between fuel and oxidizer, usually air) into electrical energy with high efficiency (up to $80 \%$ using cogeneration technology), use not only hydrogen but also various hydrocarbons as fuel (in particular, methane, propane, and natural gas) and biofuels, as well as significantly minimize carbon dioxide emissions into the atmosphere [7]. One of the key tasks in the development of modern energy-efficient SOFCs is to reduce their operating temperatures when creating medium-temperature fuel cells, which, in turn, will significantly expand the range of used construction materials, reduce the cost, and increase the reliability and service life of the device as a whole $[8-10]$. The solution of this problem requires the search for and development of new electrolyte and electrode materials that are not inferior in their performance characteristics to the traditionally used components in the formation of high-temperature SOFCs $[11-15]$. Thus, promising candidates for the role of a cathode for medium-temperature solid oxide fuel cells are oxides with a perovskite structure based on lanthanum cobaltite doped with strontium and iron $\left(\mathrm{La}_{1-x} \mathrm{Sr}_{x} \mathrm{Co}_{y} \mathrm{Fe}_{1-y} \mathrm{O}_{3-\delta}\right.$, LSCF) [16-21]. These materials are distinguished by high values of electrical conductivity (350-400 S/cm for the composition $\left.\mathrm{La}_{0.6} \mathrm{Sr}_{0.4} \mathrm{Co}_{0.2} \mathrm{Fe}_{0.8} \mathrm{O}_{3-\delta}\right)$ and mixed electronic-ionic conductivity $\left(1 \times 10^{-2}\right.$ and $10^{2} \mathrm{~S} / \mathrm{cm}$ at $800^{\circ} \mathrm{C}$, respectively) along with high catalytic activity in oxygen reduction reactions. In addition, in terms of their chemical and mechanical characteristics, such solid solutions are combined with medium-temperature electrolytes based on cerium dioxide doped with rare earth elements. Thus, the linear coefficient of thermal expansion for electrolytes in the $\mathrm{CeO}_{2}-\mathrm{Gd}_{2} \mathrm{O}_{3}$ system is $(11.5-11.9) \times 10^{-6} \mathrm{~K}^{-1}$, and for cathodes based on LSCF it is $(14-15.29) \times 10^{-6} \mathrm{~K}^{-1}$ [22-27]. As you 


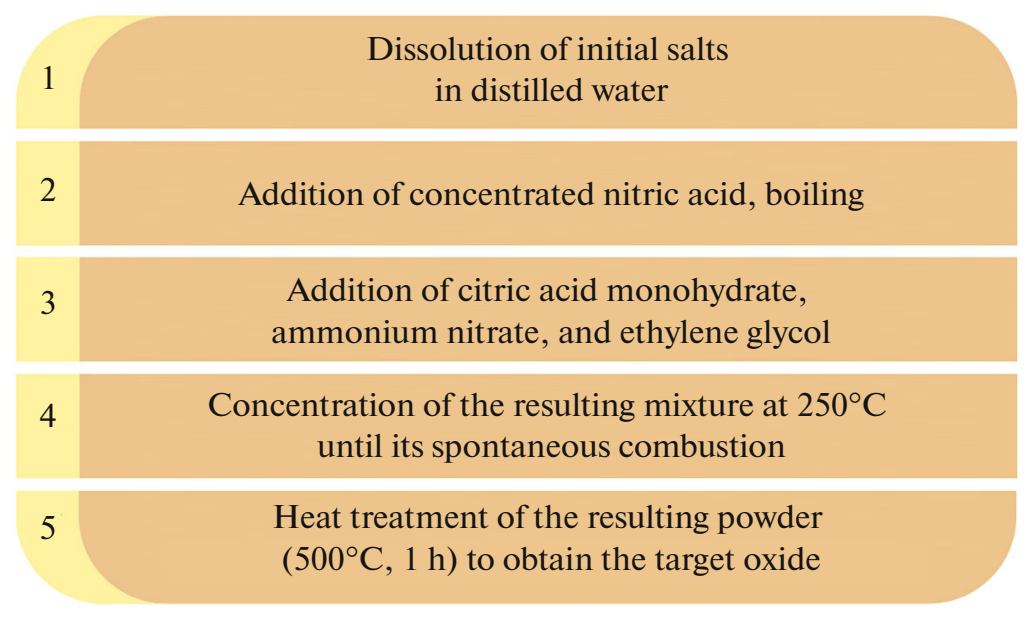

Fig. 1. Scheme of the glycol-citrate synthesis of nanopowder with the composition $\mathrm{La}_{0.6} \mathrm{Sr}_{0.4} \mathrm{Co}_{0.2} \mathrm{Fe}_{0.8} \mathrm{O}_{3}-\delta$.

know, the final functional characteristics of materials are determined by both their dispersion and microstructure. In this case, convenient and scalable methods of synthesis, which make it possible to obtain single-phase nanocrystalline materials based on $\mathrm{La}_{1-x} \mathrm{Sr}_{x} \mathrm{Co}_{y} \mathrm{Fe}_{1-} \mathrm{O}_{3-\delta}$, are combustion methods: the citrate-nitrate [28-30], glycine-nitrate [31-33], as well as glycol-citrate methods [34-37]. However, the preparation of the solid solutions by these methods requires high-temperature treatment (as a rule, above $700^{\circ} \mathrm{C}$ ) because organic components in the reaction system should be decomposed and residual carbon should be removed. In turn, this leads to a significant decrease in dispersion and porosity, which are important parameters for cathode materials. Nevertheless, by varying the ratio between the initial reagents (inorganic salts) and organic components (citric acid, ethylene glycol, as well as ammonium nitrate), it is possible to effect the completeness of the redox reaction of the formation of the target product, reducing the temperature of the subsequent heat treatment, which allows maintaining the high dispersion of the obtained materials [38].

Thus, the aim of this work was to study the process of glycol-citrate synthesis of nanopowder with the composition $\mathrm{La}_{0.6} \mathrm{Sr}_{0.4} \mathrm{Co}_{0.2} \mathrm{Fe}_{0.8} \mathrm{O}_{3-\delta}$ and investigate its thermal behavior and microstructural features.

\section{EXPERIMENTAL}

A nanopowder of composition $\mathrm{La}_{0.6} \mathrm{Sr}_{0.4} \mathrm{Co}_{0.2} \mathrm{Fe}_{0.8} \mathrm{O}_{3}$ was prepared by the glycol-citrate method. The starting reagents were barium, cobalt, and strontium nitrates and ferric chloride, the weighed portions of which were dissolved in a minimum amount of distilled water. In order to prevent contamination of the target oxide with chlorine ions, immediately before the start of the synthesis, salt solutions were boiled in the presence of nitric acid in order to replace chloride ions with nitrate ions. Then, citric acid monohydrate, ammonium nitrate, and ethylene glycol were added to the resulting reaction mixture in a molar ratio to the target product of $3: 1,6: 1$ and $2: 1$, respectively. The resulting mixture was evaporated at $250^{\circ} \mathrm{C}$ until the formation of a viscous system, which, upon further heating, combusts spontaneously to form the target foamed oxide nanopowder (Fig. 1).

The thermal behavior of the obtained nanopowder was studied using synchronous (TGA/DSC) thermal analysis carried out using an SDT Q-600 thermal analyzer. Controlled heating was performed in $\mathrm{Al}_{2} \mathrm{O}_{3}$ microcrucibles in the temperature range $20-1000^{\circ} \mathrm{C}$ at a rate of $10 \mathrm{~K} / \mathrm{min}$ in an airflow of $250 \mathrm{~mL} / \mathrm{min}$.

The IR transmission spectra of the test sample were recorded using an Infralum FT-08 FT-IR spectrometer. A suspension of the powder in liquid paraffin was prepared and placed in the form of a film between $\mathrm{KBr}$ glasses. Spectral analysis was performed in the wavenumber range $350-4000 \mathrm{~cm}^{-1}$ (the signal accumulation time was $15 \mathrm{~s}$; the resolution was $1 \mathrm{~cm}^{-1}$ ).

$\mathrm{X}$-ray powder diffraction of the powder was performed on a Bruker D8 Advance diffractometer $\left(\mathrm{Cu} K_{\alpha}\right.$ radiation, $2 \theta$ angle range $20^{\circ}-80^{\circ}$, resolution $0.02^{\circ}$, and signal accumulation time at a point $0.3 \mathrm{~s}$ ).

The microstructure and elemental composition of the obtained powder were studied using scanning electron microscopy (SEM) on an NVision 40 three-beam workstation (Carl Zeiss) equipped with an Oxford Instruments X-MAX 80 energy dispersive microprobe analyzer.

\section{RESULTS AND DISCUSSION}

The thermal behavior of the powder obtained from the glycol-citrate synthesis was investigated using a synchronous thermal analysis in a stream of air. When the powder is heated to $1000^{\circ} \mathrm{C}$, the thermal curve (Fig. 2) shows six stages of weight loss $(\Delta m=73.11 \%)$, the first two of which (2.32 and 5.20\%) are observed in 


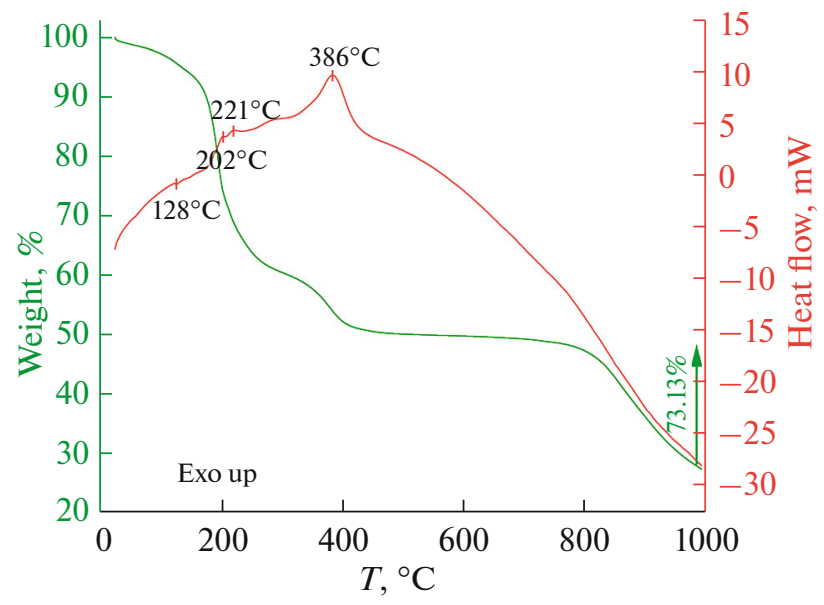

Fig. 2. TGA (green) and DSC (red) curves in an air flow for the resulting powder.

the temperature range $20-175^{\circ} \mathrm{C}$ and are accompanied by a low-intensity endotherm with a minimum at $128^{\circ} \mathrm{C}$, which is associated with the removal of sorbed atmospheric gases and water. At the next stage (175$\left.300^{\circ} \mathrm{C}\right)$, the largest weight loss $(32.13 \%)$ occurs, which corresponds to two exotherms with maxima at 202 and $221^{\circ} \mathrm{C}$ associated with the oxidation of organic components present in the reaction system. Further, in the temperature range of $300-500^{\circ} \mathrm{C}$, an intense exotherm $(\Delta m=10.55 \%)$ is observed, which is caused by the oxidation of residual carbon formed during the oxidation reaction at the previous stage. In the course of further heating in the temperature ranges of 500765 and $765-1000^{\circ} \mathrm{C}$, two stages of weight loss are observed (1.73 and $21.20 \%$, respectively). In order to oxidize the residual organic components of the reaction system and form an oxide nanopowder of the desired composition, the conditions for further heat treatment were chosen: heating to $500^{\circ} \mathrm{C}$ and isothermal holding for $1 \mathrm{~h}$.

The powders obtained after synthesis, as well as after additional heat treatment $\left(500^{\circ} \mathrm{C}, 1 \mathrm{~h}\right)$, were investigated using FTIR spectroscopy (Fig. 3). It can be seen that the spectrum of the powder obtained after the synthesis contains absorption bands in the range of $3100-3700 \mathrm{~cm}^{-1}$, which correspond to the stretching vibrations of $\mathrm{OH}$ groups. In the range $1750-1530 \mathrm{~cm}^{-1}$, absorption bands characteristic of stretching vibrations of the $\mathrm{C}-\mathrm{O}, \mathrm{C}=\mathrm{O}$, and $\mathrm{OH}$ groups are also observed [39]. In addition, in the range $1180-800 \mathrm{~cm}^{-1}$, there are characteristic bands of stretching vibrations of the $\mathrm{C}-\mathrm{O}$ and $\mathrm{C}-\mathrm{O}-\mathrm{C}$ groups [40]. After the powder was calcined, the intensity of the absorption bands corresponding to the vibrations of the $\mathrm{OH}$ bonds decreases significantly and the absorption bands corresponding to the vibrations of carbonate and carbonyl groups disappear. In this case, the spectra before and after heat treatment contain bands with maxima at 660 and $575 \mathrm{~cm}^{-1}$, corresponding to vibrations of the La-

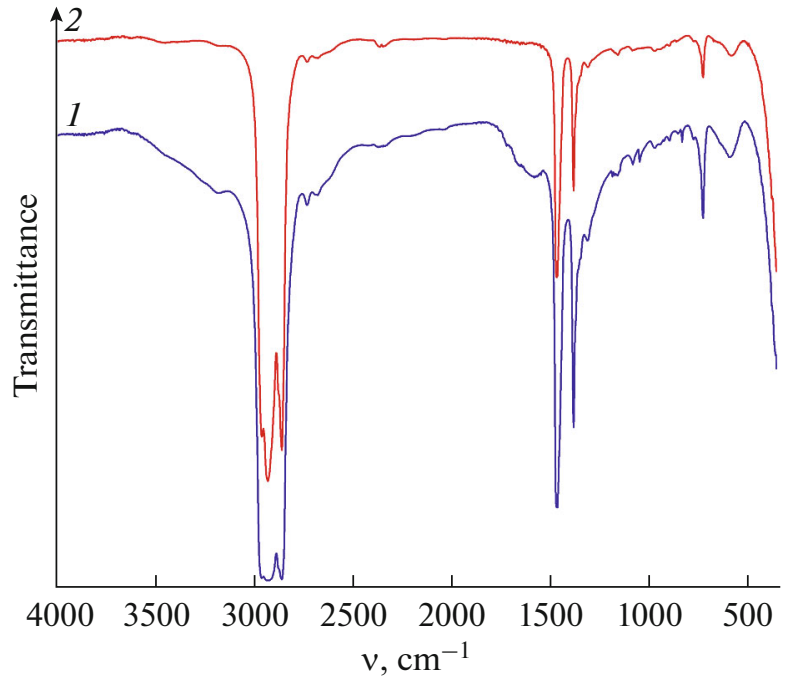

Fig. 3. IR transmission spectra of the powder obtained by (1) the glycol-citrate synthesis and (2) subsequent heat treatment at $500^{\circ} \mathrm{C}$ for $1 \mathrm{~h}$.

$\mathrm{O}$ and $\mathrm{Fe}-\mathrm{O}$ bonds $[41,42]$, which indicates the formation of a compound of the target composition.

The crystal structure of the powder obtained after heat treatment at $500^{\circ} \mathrm{C}$ was studied by X-ray powder diffraction (Fig. 4). As can be seen from the X-ray powder diffraction pattern, the reflections with maxima at $23^{\circ}, 32^{\circ}, 41^{\circ}, 47^{\circ}, 53^{\circ}, 58^{\circ}, 68^{\circ}, 73^{\circ}$, and $78^{\circ}$ correspond to the crystallographic planes (100), (110), (111), (200), (210), (211), (220), (221, 300), and (310) of the perovskite-type cubic crystal lattice $(\operatorname{Pm} \overline{3} m)$ [43]. Thus, the X-ray powder diffraction results are in good agreement with the results of IR spectroscopy and indicate the formation of a single-phase target oxide containing no impurity crystalline inclusions. The average CSR size for a given nanopowder was calculated using the Scherrer formula: $d=K \lambda / \beta \cos \theta$, where $d$ is the average CSR size, $K=0.9$ in the approximation that the powder particles are spherical [43], $\lambda$ is the $\mathrm{X}$-ray radiation wavelength, $\beta$ is the reflection width at half maximum, and $\theta$ is the diffraction angle. Thus, the average CSR size was $26 \pm 3 \mathrm{~nm}$.

The morphology of the $\mathrm{La}_{0.6} \mathrm{Sr}_{0.4} \mathrm{Co}_{0.2} \mathrm{Fe}_{0.8} \mathrm{O}_{3-\delta}$ powder after heat treatment was studied using scanning electron microscopy. According to SEM data (Figs. 5a and 5b), it is characterized by the presence of porous agglomerates (the average pore size is $\sim 38 \mathrm{~nm}$ ), consisting of particles with an average size of $\sim 83 \mathrm{~nm}$. Thus, taking into account the X-ray powder diffraction results, it can be assumed that one particle consists, on average, of 3-4 crystallites. The elemental composition of the investigated nanopowder was monitored using X-ray spectral elemental analysis carried out in the framework of scanning electron microscopy. Analysis of the spectrum obtained (Fig. 5c) confirmed the target ratio of metals in the oxide nanopowder, as well as the absence of impurity inclusions. 


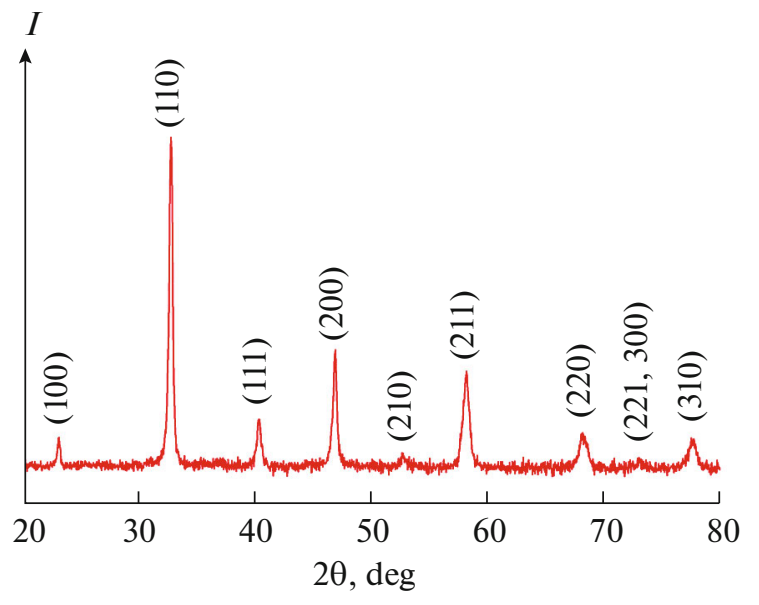

Fig. 4. X-ray diffraction pattern of nanopowder with the composition $\mathrm{La}_{0.6} \mathrm{Sr}_{0.4} \mathrm{Co}_{0.2} \mathrm{Fe}_{0.8} \mathrm{O}_{3}-\delta$ obtained after heat treatment at $500^{\circ} \mathrm{C}$.

\section{CONCLUSIONS}

The glycol-citrate synthesis of the oxide of composition $\mathrm{La}_{0.6} \mathrm{Sr}_{0.4} \mathrm{Co}_{0.2} \mathrm{Fe}_{0.8} \mathrm{O}_{3-\delta}$ has been studied. According to the results of $\mathrm{X}$-ray powder diffraction, IR spectroscopy, and X-ray spectral elemental analysis within the framework of scanning electron microscopy, it was found that this method and conditions of synthesis, as well as subsequent heat treatment, make it possible at a sufficiently low temperature $\left(500^{\circ} \mathrm{C}\right)$ to obtain a single-phase nanocrystalline powder (average CSR size $26 \pm 3 \mathrm{~nm}$ ) of the target composition, having a cubic perovskite crystal structure $(P m \overline{3} m)$ and containing no crystalline impurities.

Thus, based on the experimental data obtained using a comprehensive analysis (X-ray powder diffraction, SEM, IR spectroscopy, and synchronous thermal analysis), the synthesized oxide is of practical interest in terms of its physicochemical characteristics and microstructural features. On its basis, in the future, it is planned to prepare stable disperse systems suitable in terms of their rheological characteristics for use as functional ink in the formation of cathode coatings for medium-temperature solid oxide fuel cells using printing technologies.

\section{FUNDING}

The study was supported by the Russian Science Foundation (project no. 19-73-00354).

\section{CONFLICT OF INTEREST}

The authors declare that they have no conflicts of interest.

\section{OPEN ACCESS}

This article is licensed under a Creative Commons Attribution 4.0 International License, which permits use, sharing, adaptation, distribution and reproduction in any medium or
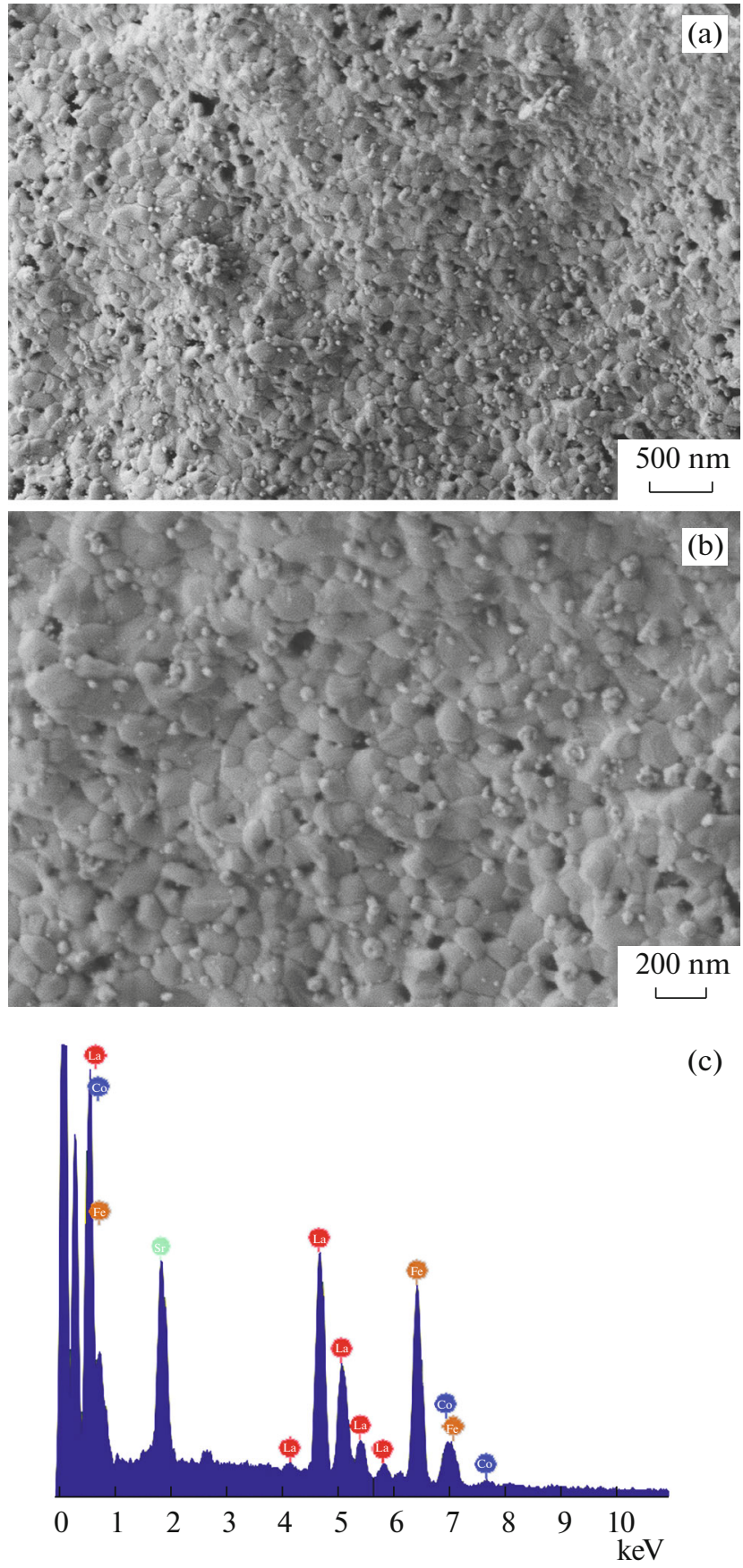

(c)

Fig. 5. Microstructure $(a, b)$ and EDX spectrum (c) the obtained nanopowder of the composition $\mathrm{La}_{0.6} \mathrm{Sr}_{0.4} \mathrm{Co}_{0.2} \mathrm{Fe}_{0.8} \mathrm{O}_{3-\delta}$.

format, as long as you give appropriate credit to the original author(s) and the source, provide a link to the Creative Commons license, and indicate if changes were made. The images or other third party material in this article are included in the article's Creative Commons license, unless indicated otherwise in a credit line to the material. If material is not included in the article's Creative Commons license and your intended use is not permitted by statutory regulation or exceeds the permitted use, you will need to obtain permission directly from 
the copyright holder. To view a copy of this license, visit http://creativecommons.org/licenses/by/4.0/.

\section{REFERENCES}

1. IEA (2019), World Energy Outlook 2019, IEA, Paris https://www.iea.org/reports/world-energy-outlook-2019

2. U.S. Energy Information Administration, International Energy Outlook 2019 with projections to 2050, 2019. https://www.eia.gov/outlooks/ieo/

3. Fuel Cell and Hydrogen Technology: Europe's Journey to a Greener World, Fuel Cells and Hydrogen Joint Undertaking, 2017.

https://doi.org/10.2843/875050

4. State of the States: Fuel Cells in America, U.S. Department of Energy, Office of Energy Efficiency\& Renewable Energy. 2018. https://www.energy.gov/sites/prod/ files/2018/06/f52/fcto_state_of_states_2017_0.pdf

5. T. L. Simonenko, N. P. Simonenko, A. S. Mokrushin, et al., Ceram. Int. 46, 121 (2020).

https://doi.org/10.1016/j.ceramint.2019.08.241

6. I. Sreedhar, B. Agarwal, P. Goyal, et al., J. Electroanal. Chem. 848, 113315 (2019).

https://doi.org/10.1016/j.jelechem.2019.113315

7. D. Thiruselvi, P. S. Kumar, M. A. Kumar, et al., Int. J. Hydrogen En. (2020).

https://doi.org/10.1016/j.ijhydene.2020.10.023

8. R. K. Pachauri and Y. K. Chauhan, Renew. Sustain. En. Rev. 43, 1301 (2015).

https://doi.org/10.1016/j.rser.2014.11.098

9. T. L. Simonenko, M. V. Kalinina, N. P. Simonenko, et al., Int. J. Hydrogen En. 44, 20345 (2019). https://doi.org/10.1016/j.ijhydene.2019.05.231

10. A. J. Jacobson, Chem. Mater. 22, 660 (2010). https://doi.org/10.1021/cm902640j

11. T. L. Simonenko, N. P. Simonenko, E. P. Simonenko, et al., Russ. J. Inorg. Chem. 64, 1475 (2019). https://doi.org/10.1134/S0036023619120167

12. M. V. Kalinina, L. V. Morozova, I. I. Khlamov, et al., Glas. Phys. Chem. 40 (5) (2014).

https://doi.org/10.1134/S108765961405006X

13. T. L. Simonenko, V. M. Ivanova, N. P. Simonenko, et al., Russ. J. Inorg. Chem. 64, 1753 (2019). https://doi.org/10.1134/S0036023619140080

14. J. Carneiro and E. Nikolla, Nano Res. 12, 2081 (2019). https://doi.org/10.1007/s12274-019-2375-y

15. Y. Sun, S. He, M. Saunders, et al., Int. J. Hydrogen En. (2020).

https://doi.org/10.1016/j.ijhydene.2020.10.113

16. X. Lou, S. Wang, Z. Liu, et al., Solid State Ionics 180, 1285 (2009).

https://doi.org/10.1016/j.ssi.2009.06.014

17. M. Liu, M. Liu, D. Ding, et al., Int. J. Hydrogen En. 37, 8613 (2012).

https://doi.org/10.1016/j.ijhydene.2012.02.139

18. S. P. Jiang, S. Zhang, and Y. D. Zhen, J. Electrochem. Soc. 153, A127 (2006). https://doi.org/10.1149/1.2136077

19. D. Gostovic, J. R. Smith, D. P. Kundinger, et al., Electrochem. Solid-State Lett. 10 (12), 214 (2007). https://doi.org/10.1149/1.2794672

20. F. Shen and K. Lu, Fuel Cells 18 (4), 457 (2018). https://doi.org/10.1002/fuce.201800044

21. S. P. Jiang, Int. J. Hydrogen En. 44, 7448 (2019). https://doi.org/10.1016/j.ijhydene.2019.01.212
22. P. Qiu, X. Yang, L. Zou, et al., ACS Appl. Mater. Interfaces 12, 29133 (2020).

https://doi.org/10.1021/acsami.0c01962

23. AliS. A. Muhammed, J. Raharjo, M. Anwar, et al., Appl. Sci. 10 (11) (2020).

https://doi.org/10.3390/app10113761

24. I. Ismail, N. Osman, and A. M. M. Jani, J. Sol-Gel Sci. Technol. 94, 435 (2020).

https://doi.org/10.1007/s10971-020-05231-0

25. A. Esquirol, N. P. Brandon, J. A. Kilner, et al., J. Electrochem. Soc. 151, A1847 (2004). https://doi.org/10.1149/1.1799391

26. E. Mostafavi, A. Babaei, and A. Ataie, Iran. J. Hydrog. Fuel Cell 2, 239 (2014).

27. W. G. Wang and M. Mogensen, Solid State Ionics 176, 457 (2005). https://doi.org/10.1016/j.ssi.2004.09.007

28. G. H. Zhou, X. Z. Fu, J. L. Luo, et al., Mater. Technol 28 (1-2), 3 (2013). https://doi.org/10.1179/1753555712Y.0000000035

29. L. Nie, Z. Liu, M. Liu, et al., J. Electrochem. Sci. Technol. 1 (1), 50 (2010). https://doi.org/10.5229/jecst.2010.1.1.050

30. Y. Liu, S. Hashimoto, H. Nishino, et al., J. Power Sources 164, 56 (2007). https://doi.org/10.1016/j.jpowsour.2006.10.093

31. Ali S. A. Muhammed, M. Anwar, M. R. Somalu, et al., Ceram. Int. 43, 4647 (2017). https://doi.org/10.1016/j.ceramint.2016.12.136

32. W. Zhou, Z. Shao, R. Ran, et al., J. Am. Ceram. Soc. 91, 1155 (2008). https://doi.org/10.1111/j.1551-2916.2007.02242.x

33. Z. Lei, Q. Zhu, and L. Zhao, J. Power Sources 161, 1169 (2006). https://doi.org/10.1016/j.jpowsour.2006.06.016

34. A. Chrzan, J. Karczewski, M. Gazda, et al., J. Solid State Electrochem. 19, 1807 (2015). https://doi.org/10.1007/s10008-015-2815-X

35. M. Ghouse, Y. Al-Yousef, A. Al-Musa, et al., Int. J. Hydrogen En. 35, 9411 (2010). https://doi.org/10.1016/j.ijhydene.2010.04.144

36. S. Guo, H. Wu, F. Puleo, et al., Catalysts 5, 366 (2015). https://doi.org/10.3390/catal5010366

37. I. Ismail, A. M. M. Jani, and N. Osman, AIP Conf. Proc. 1877 (2017). https://doi.org/10.1063/1.4999860

38. N. P. Simonenko, K. A. Sakharov, E. P. Simonenko, et al., Russ. J. Inorg. Chem. 60, 1452 (2015). https://doi.org/10.1134/S0036023615120232

39. C. Bohlender, M. Kahnes, R. Muller, et al., J. Mater. Sci. 54, 1136 (2019). https://doi.org/10.1007/s10853-018-2916-X

40. S. F. Chin, A. N. B. Romainor, S. C. Pang, et al., J. Drug Deliv. Sci. Technol. 54, 101239 (2019). https://doi.org/10.1016/j.jddst.2019.101239

41. N. T. Thuy and D. le Minh, Adv. Mater. Sci. Eng. 2012 (3) (2012). https://doi.org/10.1155/2012/380306

42. M. Hussain, M. Muneer, G. Abbas, et al., Ceram. Int. 46, 18208 (2020). https://doi.org/10.1016/j.ceramint.2020.04.143

43. AliS. A. Muhammed, M. Anwar, N. A. Baharuddin, et al., J. Solid State Electrochem. 22, 263 (2018). https://doi.org/10.1007/s10008-017-3754-5

Translated by $V$. Avdeeva 